\title{
THE CIRCULATORY EFFECTS OF HEMATOCRIT VARIATIONS IN NORMOVOLEMIC AND HYPERVOLEMIC DOGS *
}

BY JOHN F. MURRAY, PHILIP GOLD, AND B. LAMAR JOHNSON, Jr.

(From the Departments of Medicine and Physiology, University of California Medical Center, Los Angeles, Calif.)

(Submitted for publication November 5, 1962; accepted March 21, 1963)

Acute anemia can be induced by two different experimental techniques. Normovolemic anemia is produced by the withdrawal of blood that is replaced by an equal volume of plasma or suitable substitute; dilution of the initial red-cell mass by the infusion of an appropriate fluid results in hypervolemic anemia. The effects on the circulation of these two kinds of anemia have been shown to be comparable, and have led to the concept that the hematocrit level is the only factor that determines the responses $(1,2)$. This conclusion implies that a change in blood volume does not elicit independent regulatory activity.

There are only limited data available on the circulatory reactions to acutely induced polycythemia. Cardiac output has been shown to decrease in normovolemic polycythemia $(3,4)$ and increase in hypervolemic polycythemia (5). These contrasting results suggest that the difference in blood volume may account for the change in cardiac minute volumes at comparable hematocrit elevations.

The purpose of the present experiments was to reconcile these apparent discrepancies through a study of the circulatory responses to hematocrit variations in normovolemic and hypervolemic dogs. The findings indicate that both the blood volume and hematocrit level have independent regulatory effects on the circulation, and that the observed changes depend upon the interaction of these two variables.

\section{MATERIALS AND METHODS}

Studies were performed on 20 mongrel dogs anesthetized with iv pentobarbital and given supplements as needed to maintain light anesthesia. All animals had been splenectomized at least 4 weeks before the experiment. Polyethylene cannulas (PE 205; o.d., 0.082 inch)

\footnotetext{
* Supported in part by grant H-5459 from the U. S.
} Public Health Service. were placed in the femoral arteries for pressure recording and sampling and in a femoral vein for infusion. The right atrium was catheterized via the external jugular vein with a no. 8 cardiac catheter as a site for the injection of indicator in dye dilution studies. In seven dogs, effective right atrial filling pressure was measured with a Sanborn differential manometer connected to the right atrial catheter and a mushroom catheter placed in the right pleural space through a stab wound.

Cardiac output was measured in duplicate by the indicator dilution technique with indocyanine green. Arterial blood was aspirated through a Colson densitometer ${ }^{1}$ by a Harvard constant speed pump. ${ }^{2}$ Blood was withdrawn for the preparation of standard solutions of dye at each hematocrit level studied. Hematocrit ratios were determined on arterial blood samples by centrifuging with a radius of $15 \mathrm{~cm}$ at $3,000 \mathrm{rpm}$ for 30 minutes. The animal was mechanically ventilated with a Harvard respiration pump ${ }^{2}$ through a cuffed endotracheal tube to insure adequate alveolar ventilation. At the beginning of each 20-minute adjustment period throughout the experiment, the dog's lungs were maximally inflated to minimize the formation of atelectasis. Indicator dilution and pressure curves were recorded on a Honeywell multichannel oscillograph. ${ }^{3}$

In dogs 1 to 14 (Group I) a 20-minute adjustment period was allowed after the preliminary procedures were completed and after each change in hematocrit or blood volume. Duplicate measurements of cardiac output, arterial pressure, and right atrial filling pressure were then made within a 10-minute period, and single determinations of arterial oxygen content and capacity by the technique of Van Slyke and Neill (6) ; calculations from these data included peripheral vascular resistance, systemic oxygen transport, and percentage of hemoglobin saturation. The means of duplicate measurements are used in the subsequent analyses.

Normovolemic hematocrit changes were produced by bleeding and infusing equal volumes of packed erythrocytes (polycythemia) or $6 \%$ dextran in saline (anemia). The hematocrit was altered in hypervolemic experiments in a similar manner after the animal had received a transfusion of 50 to $70 \mathrm{ml}$ per $\mathrm{kg}$ of packed erythrocytes to increase its blood volume and induce hypervolemic polycythemia.

\footnotetext{
1 The Colson Corporation, Elyria, Ohio.

2 Harvard Apparatus Company, Dover, Mass.

3 Minneapolis-Honeywell, Denver, Colo.
} 
Dogs 15 to 20 (Group II) were studied similarly during control and anemic periods with the exception that a no. 8 cardiac catheter was placed in the right renal vein under fluoroscopic guidance and a Foley catheter was in- serted into the bladder; these were used to measure renal hemodynamics that will be reported separately. Cardiac output, arterial pressure, and arterial blood samples were obtained midway in two successive 8- to 12 -

TABLE I

Data from normovolemic and hypervolemic experiments in group I animals*

\begin{tabular}{|c|c|c|c|c|c|c|c|c|c|c|c|c|c|}
\hline \multirow[b]{2}{*}{$\begin{array}{l}\text { Dog } \\
\text { no. }\end{array}$} & \multirow[b]{2}{*}{ Wt } & \multirow[b]{2}{*}{$\begin{array}{c}\text { Blood } \\
\text { vol }\end{array}$} & \multirow[b]{2}{*}{ Hct } & \multirow[b]{2}{*}{$\dot{\mathbf{Q}}$} & \multirow[b]{2}{*}{$\begin{array}{l}\text { Mean } \\
\text { A.P. }\end{array}$} & \multirow[b]{2}{*}{ PVR } & \multirow[b]{2}{*}{$\begin{array}{l}\text { Heart } \\
\text { rate }\end{array}$} & \multirow[b]{2}{*}{$\begin{array}{c}\text { Stroke } \\
\text { vol }\end{array}$} & \multirow[b]{2}{*}{$\mathrm{SO}_{2} \mathrm{~T}$} & \multirow[b]{2}{*}{ ERAP } & \multicolumn{3}{|c|}{ Arterial oxygen } \\
\hline & & & & & & & & & & & Content & Capacity & $\begin{array}{l}\text { Satur- } \\
\text { ation }\end{array}$ \\
\hline & $k g$ & & $\%$ & $\underset{\min }{\mathrm{ml} / \mathrm{kg} /}$ & $m m \mathrm{Hg}$ & $U \dagger$ & $\begin{array}{c}\text { beats } / \\
\text { min }\end{array}$ & $\begin{array}{l}m l / \\
\text { beat }\end{array}$ & $\underset{\mathrm{min}}{\mathrm{ml} / \mathrm{kg} /}$ & $m m \mathrm{Hg}$ & vol \% & vol \% & $\%$ \\
\hline 1 & 12.0 & $\begin{array}{l}\mathbf{N} \\
\mathbf{N} \\
\mathbf{N} \\
\mathbf{N}\end{array}$ & $\begin{array}{l}34.6 \\
46.5 \\
24.5 \\
14.7 \\
44.9\end{array}$ & $\begin{array}{r}137 \\
97 \\
142 \\
200 \\
100\end{array}$ & $\begin{array}{r}126 \\
108 \\
112 \\
95 \\
97\end{array}$ & $\begin{array}{r}920 \\
1,113 \\
789 \\
475 \\
970\end{array}$ & $\begin{array}{l}190 \\
144 \\
148 \\
162 \\
108\end{array}$ & $\begin{array}{r}9 \\
8 \\
12 \\
15 \\
11\end{array}$ & $\begin{array}{l}20 \\
20 \\
16 \\
14 \\
19\end{array}$ & & $\begin{array}{r}15.0 \\
20.9 \\
11.1 \\
6.8 \\
19.3\end{array}$ & $\begin{array}{r}16.5 \\
22.5 \\
11.9 \\
7.3 \\
20.6\end{array}$ & $\begin{array}{l}91 \\
93 \\
93 \\
93 \\
94\end{array}$ \\
\hline 2 & 13.0 & $\begin{array}{l}\mathbf{N} \\
\mathbf{N} \\
\mathbf{N} \\
\mathbf{N}\end{array}$ & $\begin{array}{l}41.0 \\
52.1 \\
30.8 \\
16.4 \\
41.7\end{array}$ & $\begin{array}{r}78 \\
75 \\
113 \\
200 \\
123\end{array}$ & $\begin{array}{l}104 \\
97 \\
100 \\
104 \\
106\end{array}$ & $\begin{array}{r}1,333 \\
1,293 \\
885 \\
520 \\
863\end{array}$ & $\begin{array}{l}200 \\
172 \\
178 \\
174 \\
154\end{array}$ & $\begin{array}{r}5 \\
6 \\
8 \\
15 \\
10\end{array}$ & $\begin{array}{l}13 \\
17 \\
15 \\
15 \\
23\end{array}$ & & $\begin{array}{r}16.3 \\
22.6 \\
13.7 \\
7.4 \\
18.5\end{array}$ & $\begin{array}{r}18.3 \\
23.4 \\
14.3 \\
7.9 \\
19.4\end{array}$ & $\begin{array}{l}89 \\
97 \\
96 \\
93 \\
95\end{array}$ \\
\hline 3 & 20.6 & $\begin{array}{l}\mathbf{N} \\
\mathbf{N} \\
\mathbf{N} \\
\mathbf{N}\end{array}$ & $\begin{array}{l}38.5 \\
55.0 \\
30.3 \\
15.0 \\
46.8\end{array}$ & $\begin{array}{r}105 \\
49 \\
179 \\
301 \\
75\end{array}$ & $\begin{array}{l}129 \\
98 \\
123 \\
114 \\
124\end{array}$ & $\begin{array}{r}1,129 \\
2,000 \\
687 \\
379 \\
1,653\end{array}$ & $\begin{array}{l}180 \\
128 \\
162 \\
167 \\
114\end{array}$ & $\begin{array}{r}12 \\
8 \\
23 \\
37 \\
14\end{array}$ & $\begin{array}{l}17 \\
11 \\
24 \\
21 \\
15\end{array}$ & & $\begin{array}{r}16.1 \\
23.3 \\
13.6 \\
7.0 \\
20.2\end{array}$ & $\begin{array}{r}18.1 \\
25.6 \\
14.7 \\
7.9 \\
21.0\end{array}$ & $\begin{array}{l}89 \\
91 \\
93 \\
89 \\
96\end{array}$ \\
\hline 1 & 13.5 & $\begin{array}{l}N \\
N \\
N \\
\mathrm{HV} \\
\mathrm{N}\end{array}$ & $\begin{array}{l}40.5 \\
62.6 \\
38.8 \\
21.2 \\
16.4\end{array}$ & $\begin{array}{r}201 \\
66 \\
170 \\
572 \\
145\end{array}$ & $\begin{array}{l}151 \\
120 \\
132 \\
142 \\
108\end{array}$ & $\begin{array}{r}751 \\
1,818 \\
776 \\
248 \\
746\end{array}$ & $\begin{array}{r}191 \\
97 \\
188 \\
155 \\
184\end{array}$ & $\begin{array}{l}14 \\
9 \\
12 \\
50 \\
11\end{array}$ & $\begin{array}{l}35 \\
18 \\
29 \\
55 \\
10\end{array}$ & $\begin{array}{l}6.0 \\
3.1 \\
3.0 \\
8.7 \\
4.0\end{array}$ & $\begin{array}{r}17.6 \\
27.2 \\
17.1 \\
9.6 \\
7.2\end{array}$ & $\begin{array}{r}18.7 \\
28.8 \\
17.9 \\
9.8 \\
7.6\end{array}$ & $\begin{array}{l}94 \\
94 \\
96 \\
98 \\
95\end{array}$ \\
\hline 5 & 10.7 & $\stackrel{N}{N}$ & $\begin{array}{l}35.7 \\
65.1\end{array}$ & $\begin{array}{l}99 \\
54\end{array}$ & $\begin{array}{l}138 \\
127\end{array}$ & $\begin{array}{l}1,394 \\
2,352\end{array}$ & $\begin{array}{l}141 \\
151\end{array}$ & $\begin{array}{l}8 \\
4\end{array}$ & $\begin{array}{l}16 \\
15\end{array}$ & & $\begin{array}{l}16.1 \\
27.8\end{array}$ & $\begin{array}{l}17.3 \\
28.8\end{array}$ & $\begin{array}{l}93 \\
97\end{array}$ \\
\hline 6 & 6.0 & $\begin{array}{l}\mathrm{N} \\
\mathrm{HV} \\
\mathrm{HV} \\
\mathrm{HV} \\
\mathrm{N}\end{array}$ & $\begin{array}{l}42.9 \\
59.0 \\
45.3 \\
30.4 \\
27.9\end{array}$ & $\begin{array}{l}178 \\
269 \\
348 \\
400 \\
245\end{array}$ & $\begin{array}{r}112 \\
104 \\
96 \\
103 \\
71\end{array}$ & $\begin{array}{l}629 \\
387 \\
276 \\
258 \\
290\end{array}$ & $\begin{array}{r}121 \\
119 \\
115 \\
113 \\
84\end{array}$ & $\begin{array}{r}9 \\
14 \\
18 \\
21 \\
18\end{array}$ & $\begin{array}{l}32 \\
68 \\
66 \\
57 \\
29\end{array}$ & $\begin{array}{l}4.9 \\
5.3 \\
7.0 \\
6.7 \\
6.7\end{array}$ & $\begin{array}{l}18.0 \\
25.4 \\
19.1 \\
14.2 \\
11.9\end{array}$ & $\begin{array}{l}20.7 \\
27.6 \\
20.8 \\
14.9 \\
12.9\end{array}$ & $\begin{array}{l}87 \\
92 \\
92 \\
95 \\
92\end{array}$ \\
\hline 7 & 9.3 & $\begin{array}{l}\mathrm{N} \\
\mathrm{HV} \\
\mathrm{HV} \\
\mathrm{HV}\end{array}$ & $\begin{array}{l}47.1 \\
74.1 \\
47.2 \\
20.2\end{array}$ & $\begin{array}{l}129 \\
115 \\
211 \\
344\end{array}$ & $\begin{array}{r}156 \\
116 \\
109 \\
99\end{array}$ & $\begin{array}{r}1,209 \\
1,009 \\
517 \\
288\end{array}$ & $\begin{array}{l}172 \\
115 \\
121 \\
117\end{array}$ & $\begin{array}{r}7 \\
9 \\
16 \\
27\end{array}$ & $\begin{array}{l}26 \\
36 \\
43 \\
30\end{array}$ & $\begin{array}{l}3.4 \\
6.4 \\
5.6 \\
6.0\end{array}$ & $\begin{array}{r}20.4 \\
31.2 \\
20.4 \\
8.7\end{array}$ & $\begin{array}{r}22.2 \\
33.9 \\
21.8 \\
9.5\end{array}$ & $\begin{array}{l}92 \\
92 \\
94 \\
91\end{array}$ \\
\hline 8 & 12.5 & $\begin{array}{l}\mathrm{N} \\
\mathrm{HV} \\
\mathrm{HV} \\
\mathrm{HV}\end{array}$ & $\begin{array}{l}40.6 \\
71.9 \\
50.5 \\
27.6\end{array}$ & $\begin{array}{l}171 \\
120 \\
214 \\
274\end{array}$ & $\begin{array}{l}138 \\
107 \\
121 \\
129\end{array}$ & $\begin{array}{l}807 \\
892 \\
566 \\
471\end{array}$ & $\begin{array}{l}177 \\
119 \\
112 \\
107\end{array}$ & $\begin{array}{l}12 \\
13 \\
24 \\
32\end{array}$ & $\begin{array}{l}33 \\
35 \\
46 \\
32\end{array}$ & $\begin{array}{l}4.4 \\
7.7 \\
7.4 \\
7.9\end{array}$ & $\begin{array}{l}19.5 \\
29.1 \\
21.4 \\
11.7\end{array}$ & $\begin{array}{l}21.7 \\
32.3 \\
23.5 \\
12.9\end{array}$ & $\begin{array}{l}90 \\
90 \\
91 \\
91\end{array}$ \\
\hline 9 & 14.7 & $\begin{array}{l}\mathrm{N} \\
\mathrm{HV} \\
\mathrm{HV} \\
\mathrm{HV} \\
\mathrm{N}\end{array}$ & $\begin{array}{l}45.2 \\
73.0 \\
48.5 \\
20.9 \\
18.4\end{array}$ & $\begin{array}{l}134 \\
67 \\
224 \\
450 \\
126\end{array}$ & $\begin{array}{r}127 \\
103 \\
117 \\
124 \\
81\end{array}$ & $\begin{array}{r}948 \\
1,537 \\
523 \\
276 \\
643\end{array}$ & $\begin{array}{l}180 \\
187 \\
183 \\
170 \\
170\end{array}$ & $\begin{array}{r}11 \\
5 \\
18 \\
39 \\
11\end{array}$ & $\begin{array}{l}27 \\
19 \\
45 \\
39 \\
10\end{array}$ & & $\begin{array}{r}19.8 \\
28.3 \\
20.2 \\
8.7 \\
7.9\end{array}$ & $\begin{array}{r}21.0 \\
33.9 \\
22.5 \\
9.7 \\
8.5\end{array}$ & $\begin{array}{l}94 \\
83 \\
90 \\
90 \\
93\end{array}$ \\
\hline 10 & 13.0 & $\begin{array}{l}\mathrm{N} \\
\mathrm{HV} \\
\mathrm{HV} \\
\mathrm{HV} \\
\mathrm{N}\end{array}$ & $\begin{array}{l}39.3 \\
60.3 \\
37.8 \\
18.0 \\
17.7\end{array}$ & $\begin{array}{l}111 \\
71 \\
208 \\
325 \\
142\end{array}$ & $\begin{array}{r}119 \\
91 \\
124 \\
110 \\
85\end{array}$ & $\begin{array}{r}1,072 \\
1,282 \\
594 \\
338 \\
599\end{array}$ & $\begin{array}{l}160 \\
121 \\
131 \\
148 \\
163\end{array}$ & $\begin{array}{r}9 \\
8 \\
21 \\
29 \\
11\end{array}$ & $\begin{array}{l}20 \\
18 \\
35 \\
26 \\
11\end{array}$ & & $\begin{array}{r}17.6 \\
25.8 \\
16.8 \\
7.9 \\
7.6\end{array}$ & $\begin{array}{r}18.0 \\
27.6 \\
17.3 \\
8.2 \\
8.2\end{array}$ & $\begin{array}{l}98 \\
93 \\
97 \\
96 \\
93\end{array}$ \\
\hline 11 & 16.4 & $\begin{array}{l}\mathrm{N} \\
\mathrm{HV} \\
\mathrm{HV} \\
\mathrm{HV}\end{array}$ & $\begin{array}{l}40.1 \\
56.5 \\
39.8 \\
18.2\end{array}$ & $\begin{array}{r}126 \\
93 \\
139 \\
191\end{array}$ & $\begin{array}{r}122 \\
112 \\
105 \\
86\end{array}$ & $\begin{array}{r}968 \\
1,204 \\
755 \\
450\end{array}$ & $\begin{array}{l}164 \\
140 \\
137 \\
140\end{array}$ & $\begin{array}{l}13 \\
11 \\
17 \\
22\end{array}$ & $\begin{array}{l}23 \\
23 \\
24 \\
15\end{array}$ & & $\begin{array}{r}18.3 \\
24.8 \\
17.2 \\
8.0\end{array}$ & $\begin{array}{r}19.6 \\
27.8 \\
19.2 \\
8.4\end{array}$ & $\begin{array}{l}93 \\
89 \\
90 \\
95\end{array}$ \\
\hline 12 & 11.6 & $\begin{array}{l}\mathrm{N} \\
\mathrm{N} \\
\mathrm{HV} \\
\mathrm{HV} \\
\mathrm{HV}\end{array}$ & $\begin{array}{l}43.9 \\
53.0 \\
74.7 \\
42.8 \\
27.1\end{array}$ & $\begin{array}{r}165 \\
48 \\
54 \\
248 \\
347\end{array}$ & $\begin{array}{r}136 \\
59 \\
49 \\
56 \\
75\end{array}$ & $\begin{array}{r}824 \\
1,229 \\
907 \\
226 \\
216\end{array}$ & $\begin{array}{l}151 \\
108 \\
104 \\
117 \\
125\end{array}$ & $\begin{array}{r}13 \\
5 \\
6 \\
25 \\
32\end{array}$ & $\begin{array}{l}33 \\
11 \\
17 \\
50 \\
43\end{array}$ & $\begin{array}{r}2.0 \\
5.8 \\
4.5 \\
5.3 \\
10.6\end{array}$ & $\begin{array}{l}20.0 \\
23.6 \\
31.4 \\
20.0 \\
12.4\end{array}$ & $\begin{array}{l}20.7 \\
25.0 \\
35.2 \\
20.2 \\
12.8\end{array}$ & $\begin{array}{l}97 \\
94 \\
89 \\
99 \\
97\end{array}$ \\
\hline 13 & 9.1 & $\underset{\mathrm{HV}}{\mathrm{HV}}$ & $\begin{array}{l}42.9 \\
68.2 \\
33.7\end{array}$ & $\begin{array}{r}87 \\
113 \\
376\end{array}$ & $\begin{array}{r}98 \\
105 \\
105\end{array}$ & $\begin{array}{r}1,126 \\
929 \\
279\end{array}$ & $\begin{array}{l}103 \\
136 \\
144\end{array}$ & $\begin{array}{r}8 \\
8 \\
24\end{array}$ & $\begin{array}{l}16 \\
32 \\
55\end{array}$ & $\begin{array}{l}1.8 \\
3.1 \\
2.7\end{array}$ & $\begin{array}{l}18.2 \\
28.1 \\
14.5\end{array}$ & $\begin{array}{l}20.0 \\
31.0 \\
15.1\end{array}$ & $\begin{array}{l}91 \\
91 \\
96\end{array}$ \\
\hline 14 & 17.5 & $\stackrel{\mathrm{N}}{\mathrm{HV}}$ & $\begin{array}{l}41.6 \\
63.7 \\
28.5\end{array}$ & $\begin{array}{l}279 \\
178 \\
263\end{array}$ & $\begin{array}{l}127 \\
128 \\
133\end{array}$ & $\begin{array}{l}455 \\
719 \\
506\end{array}$ & $\begin{array}{l}149 \\
107 \\
101\end{array}$ & $\begin{array}{l}33 \\
29 \\
45\end{array}$ & $\begin{array}{l}47 \\
48 \\
33\end{array}$ & $\begin{array}{r}4.8 \\
4.9 \\
10.0\end{array}$ & $\begin{array}{l}16.8 \\
26.8 \\
12.5\end{array}$ & $\begin{array}{l}19.6 \\
29.1 \\
13.6\end{array}$ & $\begin{array}{l}86 \\
92 \\
92\end{array}$ \\
\hline
\end{tabular}

* Abbreviations: Hct, hematocrit; $\dot{Q}$, cardiac output; A.P., arterial pressure; PVR, peripheral vascular resistance; SO $2 \mathrm{~T}$, systemic oxygen transport; ERAP, effective right atrial filling pressure; N, normovolemic; HV, hypervolemic.

† Units = mean A.P., $\mathrm{mm} \mathrm{Hg} / \dot{\mathrm{Q}}, \mathrm{L} / \mathrm{kg} / \mathrm{min}$. 
TABLE II

Data from normovolemic and hypervolemuc experiments in group II animals*

\begin{tabular}{|c|c|c|c|c|c|c|c|c|c|c|c|c|c|}
\hline $\begin{array}{l}\text { Dog } \\
\text { no. }\end{array}$ & $\mathrm{Wt}$ & Bloo & vol & Hct & $\dot{\mathbf{Q}}$ & $\begin{array}{l}\text { Mean } \\
\text { A.P. }\end{array}$ & PVR & $\begin{array}{l}\text { Heart } \\
\text { rate }\end{array}$ & $\begin{array}{c}\text { Stroke } \\
\text { vol }\end{array}$ & $\mathrm{SO}_{2} \mathrm{~T}$ & $\mathrm{pH}$ & $\mathrm{pO}_{2}$ & $\begin{array}{l}\text { Satur- } \\
\text { ation }\end{array}$ \\
\hline & $k g$ & & $m l / k g$ & $\%$ & $\underset{\min }{\mathrm{ml} / \mathrm{kg} /}$ & $m m \mathrm{Hg}$ & $U \dagger$ & $\begin{array}{c}\text { beats/ } \\
\text { min }\end{array}$ & $\begin{array}{l}m l / \\
\text { beat }\end{array}$ & $\underset{\mathrm{min}}{\mathrm{ml} / \mathrm{kg} /}$ & & $m m \mathrm{Hg}$ & $\% \ddagger$ \\
\hline 15 & 11.8 & $\begin{array}{l}\mathrm{N} \\
\mathrm{N} \\
\mathrm{HV}\end{array}$ & $\begin{array}{r}84 \\
90 \\
122\end{array}$ & $\begin{array}{l}42.3 \\
20.4 \\
19.1\end{array}$ & $\begin{array}{l}102 \\
209 \\
195\end{array}$ & $\begin{array}{l}103 \\
112 \\
129\end{array}$ & $\begin{array}{r}1,017 \\
517 \\
663\end{array}$ & $\begin{array}{l}150 \\
129 \\
108\end{array}$ & $\begin{array}{r}8 \\
19 \\
21\end{array}$ & $\begin{array}{l}20 \\
21 \\
22\end{array}$ & $\begin{array}{l}7.52 \\
7.48 \\
7.42\end{array}$ & $\begin{array}{l}104 \\
108 \\
140\end{array}$ & $\begin{array}{l}97 \\
97 \\
98\end{array}$ \\
\hline 16 & 16.7 & $\begin{array}{l}\mathrm{N} \\
\mathrm{N} \\
\mathrm{HV}\end{array}$ & $\begin{array}{r}84 \\
94 \\
122\end{array}$ & $\begin{array}{l}37.5 \\
17.9 \\
20.3\end{array}$ & $\begin{array}{l}158 \\
327 \\
369\end{array}$ & $\begin{array}{l}103 \\
107 \\
117\end{array}$ & $\begin{array}{l}652 \\
327 \\
318\end{array}$ & $\begin{array}{l}188 \\
195 \\
178\end{array}$ & $\begin{array}{l}14 \\
28 \\
35\end{array}$ & $\begin{array}{l}25 \\
25 \\
32\end{array}$ & $\begin{array}{l}7.47 \\
7.40 \\
7.40\end{array}$ & $\begin{array}{l}83 \\
89 \\
96\end{array}$ & $\begin{array}{l}94 \\
94 \\
95\end{array}$ \\
\hline 17 & 17.5 & $\begin{array}{l}\mathrm{N} \\
\mathrm{N} \\
\mathrm{HV}\end{array}$ & $\begin{array}{r}85 \\
91 \\
128\end{array}$ & $\begin{array}{l}36.5 \\
16.8 \\
20.7\end{array}$ & $\begin{array}{l}170 \\
283 \\
334\end{array}$ & $\begin{array}{l}133 \\
128 \\
123\end{array}$ & $\begin{array}{l}794 \\
451 \\
367\end{array}$ & $\begin{array}{l}185 \\
174 \\
148\end{array}$ & $\begin{array}{l}16 \\
28 \\
40\end{array}$ & $\begin{array}{l}26 \\
22 \\
32\end{array}$ & $\begin{array}{l}7.38 \\
7.36 \\
7.31\end{array}$ & $\begin{array}{r}92 \\
94 \\
102\end{array}$ & $\begin{array}{l}94 \\
94 \\
95\end{array}$ \\
\hline 18 & 17.6 & $\begin{array}{l}\mathrm{N} \\
\mathrm{HV} \\
\mathrm{N}\end{array}$ & $\begin{array}{r}76 \\
126 \\
86\end{array}$ & $\begin{array}{l}44.1 \\
23.3 \\
20.0\end{array}$ & $\begin{array}{l}111 \\
307 \\
158\end{array}$ & $\begin{array}{l}128 \\
134 \\
118\end{array}$ & $\begin{array}{r}1,179 \\
437 \\
715\end{array}$ & $\begin{array}{l}164 \\
137 \\
132\end{array}$ & $\begin{array}{l}12 \\
39 \\
21\end{array}$ & $\begin{array}{l}21 \\
34 \\
14\end{array}$ & $\begin{array}{l}7.48 \\
7.42 \\
7.37\end{array}$ & $\begin{array}{r}91 \\
102 \\
94\end{array}$ & $\begin{array}{l}95 \\
96 \\
94\end{array}$ \\
\hline 19 & 10.7 & $\begin{array}{l}\mathrm{N} \\
\mathrm{HV} \\
\mathrm{N}\end{array}$ & $\begin{array}{r}84 \\
122 \\
84\end{array}$ & $\begin{array}{l}38.5 \\
20.5 \\
14.3\end{array}$ & $\begin{array}{l}134 \\
544 \\
235\end{array}$ & $\begin{array}{l}131 \\
136 \\
111\end{array}$ & $\begin{array}{l}994 \\
249 \\
473\end{array}$ & $\begin{array}{l}178 \\
180 \\
161\end{array}$ & $\begin{array}{r}8 \\
32 \\
16\end{array}$ & $\begin{array}{l}24 \\
47 \\
14\end{array}$ & $\begin{array}{l}7.50 \\
7.30 \\
7.34\end{array}$ & $\begin{array}{l}88 \\
81 \\
72\end{array}$ & $\begin{array}{l}95 \\
90 \\
88\end{array}$ \\
\hline 20 & 16.7 & $\begin{array}{l}\mathrm{N} \\
\mathrm{HV} \\
\mathrm{N}\end{array}$ & $\begin{array}{r}74 \\
116 \\
74\end{array}$ & $\begin{array}{l}39.2 \\
19.3 \\
15.3\end{array}$ & $\begin{array}{l}140 \\
265 \\
205\end{array}$ & $\begin{array}{l}141 \\
150 \\
150\end{array}$ & $\begin{array}{r}1,012 \\
567 \\
733\end{array}$ & $\begin{array}{l}177 \\
159 \\
165\end{array}$ & $\begin{array}{l}13 \\
28 \\
21\end{array}$ & $\begin{array}{l}25 \\
22 \\
12\end{array}$ & $\begin{array}{l}7.51 \\
7.43 \\
7.40\end{array}$ & $\begin{array}{l}90 \\
64 \\
51\end{array}$ & $\begin{array}{l}96 \\
87 \\
76\end{array}$ \\
\hline
\end{tabular}

* Abbreviations : Hct, hematocrit; $\dot{Q}$, cardiac output; A.P., arterial pressure; PVR, peripheral vascular resistance; $\mathrm{SO}_{2} \mathrm{~T}$, systemic oxygen transport; $\mathrm{pO}_{2}$, partial pressure $\mathrm{O}_{2} ; \mathrm{N}$, normovolemic; $\mathrm{HV}$, hypervolemic.

$\dagger$ Units = mean A.P., $\mathrm{mm} \mathrm{Hg} / \dot{\mathrm{Q}}, \mathrm{L} / \mathrm{kg} / \mathrm{min}$.

$\ddagger$ Percentage of saturation calculated from $\mathrm{pO}_{2}$ and $\mathrm{pH}$ data.

minute clearance periods. Percentage of hemoglobin saturation was calculated from the $\mathrm{pO}_{2}$, measured on a modified Clark electrode, and $\mathrm{pH}$, measured with a Beckman electrode, and a Beckman model 160 gas analyzer. ${ }^{4}$ Means of the two measurements at the three hematocritvolume combinations studied are used in the analyses.

Circulating blood volume was measured in Group II dogs at the three volume-hematocrit levels studied. Successive injections of 5,10 , and $15 \mu \mathrm{c}$ of radioactive iodine-labeled albumin were given immediately after samples for background radiation were obtained; 5 minutes later a single sample was drawn, weighed, and counted in a well counter. Microcuries of activity per milliliter of blood were determined by dividing the weight of the sample by the specific gravity of blood (1.054 control hematocrit, and 1.041 anemic hematocrits). Blood volume in milliliters was calculated from the microcuries injected divided by the microcuries per milliliter of blood.

\section{RESULTS}

Hematocrit. All the data in both normovolemic and hypervolemic studies are given in Tables I and II. Since all of the animals were splenectomized and studied in essentially the same man-

4 Beckman Instruments, Inc., Palo Alto, Calif. ner, the results from Groups I and II have been pooled and analyzed together. Hypervolemic and normovolemic values within four hematocrit ranges, $<24,25$ to 34,35 to 50 , and 51 to $65 \%$ have been statistically compared by $t(7)$, and the results are shown in Table III. There was no statistical difference between the mean hematocrits in any hematocrit range studied except the lowest. It is important to note that this variation, hematocrit in hypervolemia higher than normovolemia, is in the direction that would tend to reduce the magnitude of the differences in the hemodynamic data that follows. No comparison was possible at hematocrits $>65 \%$ because no normovolemic values were obtained in that range.

Cardiac output. Cardiac output was significantly higher in hypervolemia than in normovolemia in all hematocrit ranges compared (Table III). Figure 1 shows a plot of mean cardiac output against mean hematocrit for all measurements obtained within the hematocrit ranges of $<24$, 25 to 34,35 to 50,51 to 65 , and $>66 \%$. The 
figures in parentheses are the number of observations made within a given hematocrit range. The correlation coefficients for all data included in Figure 1 are $r=-0.72(\mathrm{p}<0.01)$ for normovolemic and $\mathrm{r}=-0.73(\mathrm{p}<0.01)$ for hypervolemic studies.

Peripheral vascular resistance. Data on peripheral vascular resistance (PVR) are expressed in arbitrary units, PVR units $=$ mean arterial pressure, millimeters $\mathrm{Hg}$, divided by cardiac output, liters per kilogram per minute. PVR was significantly lower in hypervolemia than in normovolemia in all hematocrit ranges compared (Table III). Figure 2 is a graph of mean PVR in hypervolemic and normovolemic experiments plotted against mean hematocrit values for the hematocrit ranges noted above. Both normovolemic and hypervolemic animals show a rise in vascular resistance that becomes progressively greater as hematocrit increases. The PVR in hypervolemia is approximately half the normovolemic value in each hematocrit range; the difference primarily reflects the elevated cardiac output in hypervolemic studies, since systemic arterial pressure was nearly the same in the two experimental groups.

Arterial oxygen saturation. No statistically significant difference could be demonstrated between arterial oxygen saturation $\left(\mathrm{SaO}_{2}\right)$ values in normovolemia and hypervolemia (Table III). Figure 3 is a graph of mean $\mathrm{SaO}_{2}$ in hypervolemic and normovolemic experiments plotted against mean hematocrit for all measurements made within the hematocrit ranges previously defined. Although the tendency shown in Figure 4 is for $\mathrm{SaO}_{2}$ to rise as hematocrit increases, the correlation coefficient for these data is only $0.27(n=44$. $\mathrm{p}>0.05)$. A significant relationship was found, however, between $\mathrm{SaO}_{2}$ and hematocrit in the hypervolemic experiments with a correlation coefficient of $-0.46(n=32, p<0.01)$. The $\mathrm{SaO}_{2}$ values in the hypervolemic experiments were low-

TABLE III

Mean values and results of statistical comparisons between hypervolemic and normovolemic data in different hematocrit ranges

\begin{tabular}{|c|c|c|c|c|}
\hline & \multicolumn{4}{|c|}{ Hematocrit range } \\
\hline & $<24$ & $25-34$ & $35-50$ & $51-65$ \\
\hline Hematocrit & \multicolumn{4}{|c|}{$\%$} \\
\hline $\begin{array}{c}\text { Hypervolemia } \\
\text { Normovolemia } \\
t \\
\mathrm{p}\end{array}$ & $\begin{array}{l}20.1 \\
16.7 \\
4.261 \\
<0.001\end{array}$ & $\begin{array}{l}29.6 \\
28.5 \\
0.614 \\
>0.5\end{array}$ & $\begin{array}{l}43.7 \\
41.6 \\
1.219 \\
>0.20\end{array}$ & $\begin{array}{l}58.2 \\
57.6 \\
10.555 \\
>0.50\end{array}$ \\
\hline Cardiac output & \multicolumn{4}{|c|}{$\mathrm{ml} / \mathrm{kg} / \min$} \\
\hline $\begin{array}{r}\text { Hypervolemia } \\
\text { Normovolemia } \\
t \\
\mathrm{p}\end{array}$ & $\begin{array}{l}354.2 \\
226.0 \\
2.940 \\
<0.01\end{array}$ & $\begin{array}{l}332.0 \\
169.8 \\
4.075 \\
<0.005\end{array}$ & $\begin{array}{l}229.7 \\
135.2 \\
4.178 \\
<0.001\end{array}$ & $\begin{array}{l}165.0 \\
58.4 \\
2.851 \\
<0.025\end{array}$ \\
\hline Peripheral vascular resistance & \multicolumn{4}{|c|}{$U($ see text) } \\
\hline $\begin{array}{c}\text { Hypervolemia } \\
\text { Normovolemia } \\
t \\
\mathrm{p}\end{array}$ & $\begin{array}{l}381.9 \\
518.9 \\
2.349 \\
<0.05\end{array}$ & $\begin{array}{l}346.0 \\
662.8 \\
2.382 \\
<0.05\end{array}$ & $\begin{array}{l}482.5 \\
983.4 \\
4.400 \\
<0.001\end{array}$ & $\begin{array}{l}831.4 \\
1738.4 \\
3.277 \\
<0.025\end{array}$ \\
\hline Arterial oxygen saturation & \multicolumn{4}{|c|}{$\%$} \\
\hline $\begin{array}{c}\text { Hypervolemia } \\
\text { Normovolemia } \\
t \\
\mathrm{p}\end{array}$ & $\begin{array}{l}93.7 \\
91.2 \\
1.165 \\
>0.20\end{array}$ & $\begin{array}{l}94.2 \\
93.8 \\
0.304 \\
>0.50\end{array}$ & $\begin{array}{l}93.3 \\
93.2 \\
0.114 \\
>0.20\end{array}$ & $\begin{aligned} & 91.6 \\
& 94.6 \\
& 2.176 \\
= & 0.07\end{aligned}$ \\
\hline Systemic oxygen transport & \multicolumn{4}{|c|}{$\mathrm{ml} / \mathrm{kg} / \mathrm{min}$} \\
\hline $\begin{array}{c}\text { Hypervolemia } \\
\text { Normovolemia } \\
t \\
\mathrm{p}\end{array}$ & $\begin{aligned} 32.3 \\
17.1 \\
3.839 \\
<0.005\end{aligned}$ & $\begin{aligned} & 43.8 \\
& 22.2 \\
& 3.172 \\
&<0.025\end{aligned}$ & $\begin{aligned} & 43.8 \\
& 24.2 \\
& 4.746 \\
&<0.001\end{aligned}$ & $\begin{array}{c}40.6 \\
15.0 \\
2.789 \\
<0.025\end{array}$ \\
\hline
\end{tabular}




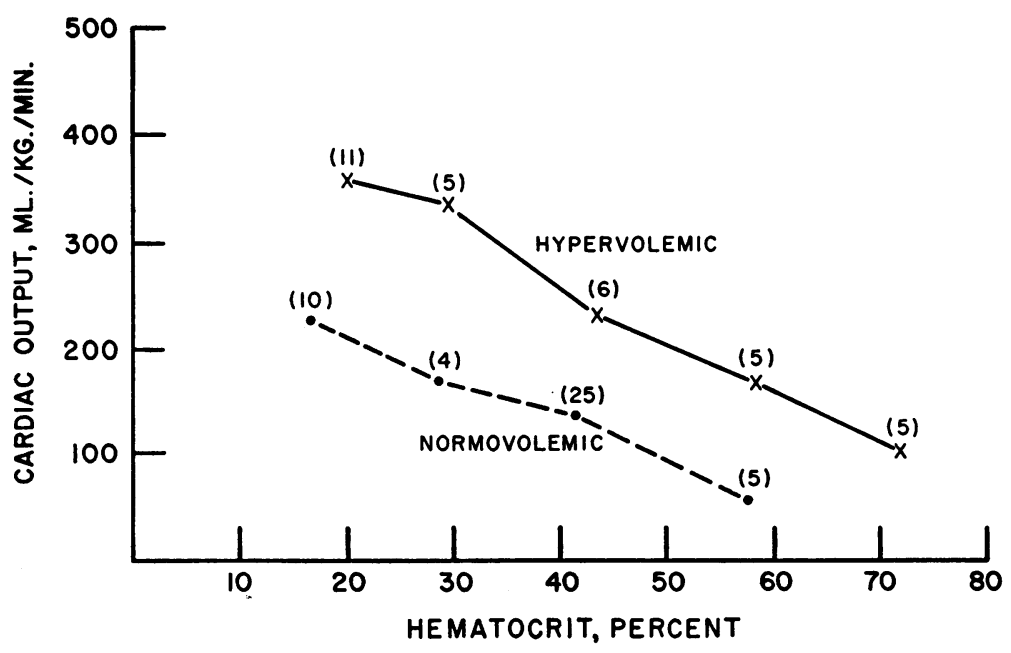

Fig. 1. Composite graph OF MEAN CARDIAC OUTPUT AND hematocrit values OBTAINED WITHIN THE HEMATOCRIT RANGES OF $<24,25$ To 34,35 To 50,51 To 65 , AND $>65 \%$. The figures within the parentheses indicate the number of observations that contributed to the data point. Normovolemic and hypervolemic studies are shown separately.

est at the highest hematocrits and had a tendency to rise as the hematocrit was reduced; this relationship is opposite to the trend in the normovolemic experiments and is considered in the discussion.

Systemic oxygen transport. Systemic oxygen transport $\left(\mathrm{SO}_{2} \mathrm{~T}\right.$, milliliters per kilogram per minute) is calculated by multiplying cardiac output (milliliters per kilogram per minute) by arterial oxygen content (milliliter per milliliter); it represents the amount of oxygen transported to the body tissues per minute. $\mathrm{SO}_{2} \mathrm{~T}$ was significantly higher in hypervolemia than in normovolemia in all hematocrit ranges analyzed (Table III). Figure 4 shows a graph of mean $\mathrm{SO}_{2} \mathrm{~T}$ in hypervolemic and normovolemic experiments plotted

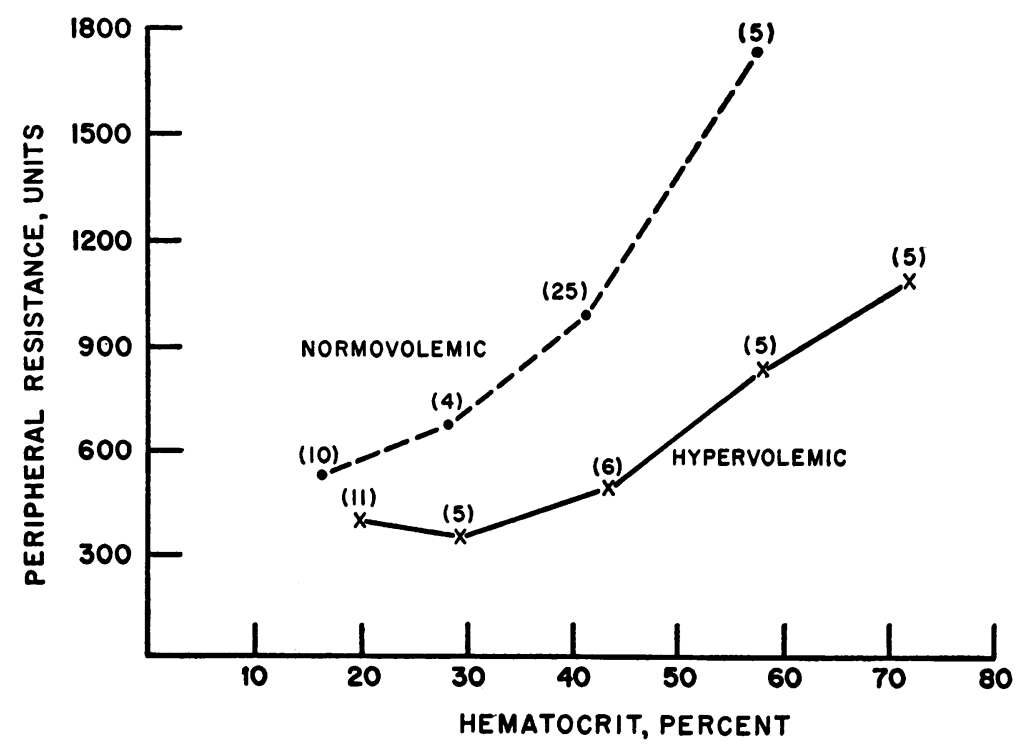

Fig. 2. Composite grapH of MEAN PERIPHERAL vascular Resistance (SEe TEXT) AND hematocrit values COMpIIEd as Indicated in Figure 1. 


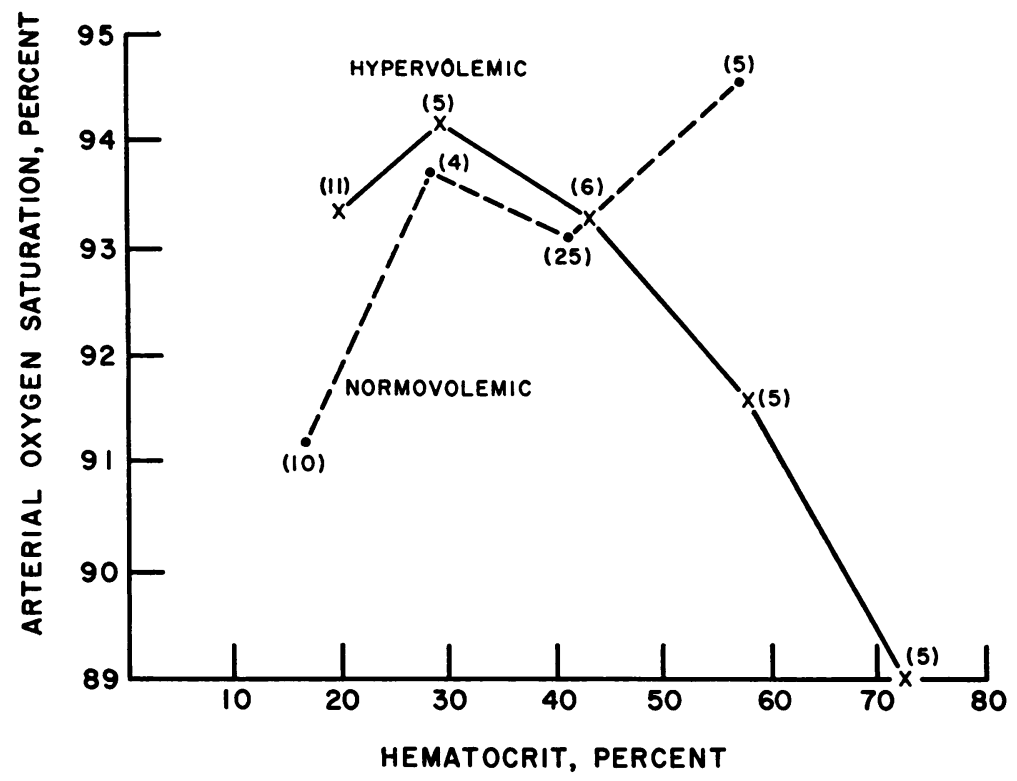

Fig. 3. COMPOSITE GRAPH OF MEAN ARTERIAL OXYGEN SATURATION AND hematocrit values compiled as indicated in Figure 1.

against mean hematocrit for the same hematocrit ranges defined previously. An inverted U-shaped curve was found for both normovolemic and hypervolemic studies with the highest values in the normal hematocrit range ( 35 to $50 \%$ ). The hypervolemic curve was flatter in the middle with $\mathrm{SO}_{2} \mathrm{~T}$ equal in the 25 to $34 \%$ and 35 to $50 \%$ hematocrit ranges. The elevated cardiac outputs in the hypervolemic experiments are reflected in higher $\mathrm{SO}_{2} \mathrm{~T}$ values that are approximately twice the normovolemic results at any comparable he. matocrit. The differences in $\mathrm{SaO}_{2}$ in normovolemia and hypervolemia are small and do not influence the general shape of the curves shown in Figure 4, or account for the differences in $\mathrm{SO}_{2} \mathrm{~T}$ between the two groups.

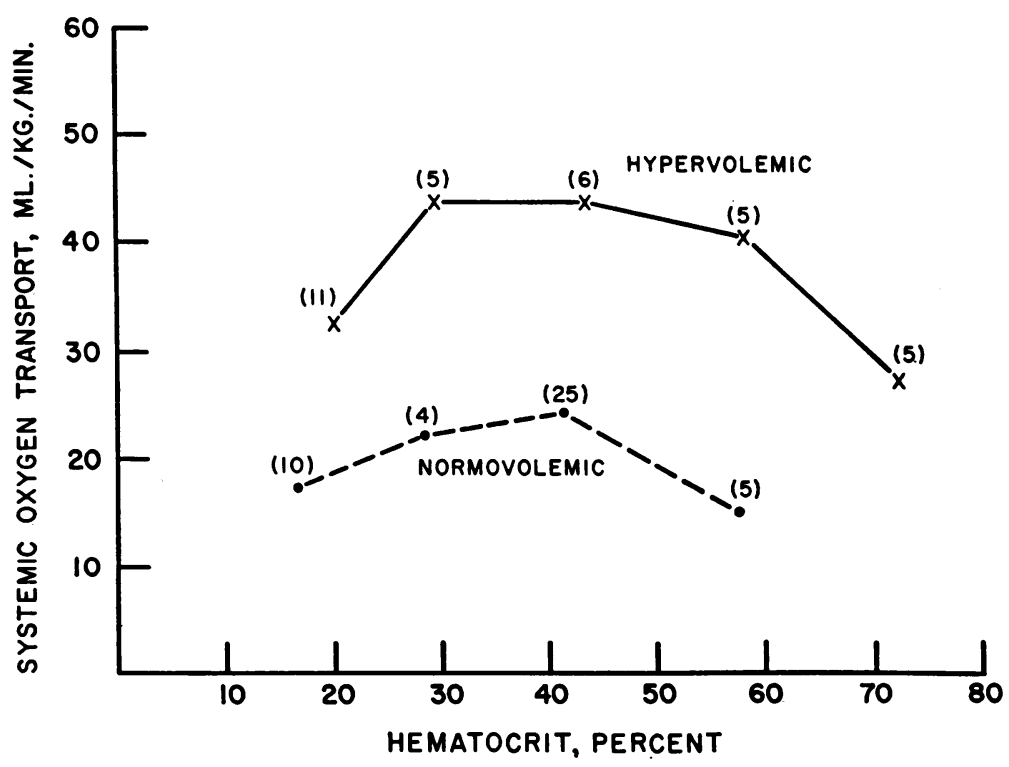

Fig. 4. COMPOSITE GRAPH OF THE MEAN SYSTEMIC OXYGEN TRANSPORT AND heMatocrit values COMPIIED as INDICATEd IN Figure 1. 
Right atrial filling pressure. Measurements of effective right atrial filling pressure (ERAP) were made in seven dogs and are reported in $\mathrm{Ta}$ ble I. All seven animals had a rise in ERAP above the initial normovolemic level at some time after the blood volume was increased. There was no relationship between the change in ERAP and the rise in cardiac output as hematocrit was reduced in hypervolemic experiments. In four dogs, the variation in successive studies was less than $2 \mathrm{~mm}$ of $\mathrm{Hg}$. Only two animals had substantial elevations of 6.1 and $5.1 \mathrm{~mm} \mathrm{Hg}$ following the reduction in hematocrit.

Arterial pressure, heart rate, and stroke volume. The changes in mean arterial pressure were variable and usually less than $30 \mathrm{~mm} \mathrm{Hg}$. In general, in both hypervolemic and normovolemic experiments, the arterial pressures were approximately the same and tended to be lower at high hematocrits than at reduced hematocrits. In dogs 6 to 12, in which there were three successive hypervolemic studies, as the hematocrit was lowered, the mean arterial pressure rose in four, decreased in two, and was essentially unchanged in one.

The changes in heart rate were also variable and did not always parallel the variation in cardiac output. An inverse relationship between blood volume and heart rate, previously noted in variable volume studies in normal human subjects (8), was not encountered in our experiments. This is probably explained by the pentobarbital anesthesia that caused a tachycardia in most dogs. In contrast to the inconsistent relationship between cardiac output and heart rate, changes in stroke volume always followed those in cardiac output (Tables I and II). This relationship was the same in both normal and increased blood volume studies; in each hematocrit range, however, stroke volume per kilogram was higher in hypervolemia than in normovolemia.

Blood volume. Total circulating blood volume was measured by the dilution of radioactive iodine-labeled albumin ${ }^{5}$ at all hematocrit-volume combinations studied in Group II animals (Table II). Dogs 15 to 17 had normovolemic studies at control and subsequent anemic hematocrits in which the blood volume remained constant within

5 Kindly supplied and counted by Dr. Leslie R. Bennett.
$12 \%$; an elevation of 6,10 , and $6 \mathrm{ml}$ per $\mathrm{kg}$ was noted between the two normovolemic determinations in the three dogs. It was noted, however, that the increase in blood volume during the hypervolemic measurements was always less than anticipated from the amount of dextran and erythrocytes infused. This discrepancy was assumed to be due to extravascular distribution of dextran, and excess fluid found in the abdomen when the experiment was completed supports this impression. For these reasons in dogs 18 to 20, which were made hypervolemic and anemic in the second period, less blood ( $40 \mathrm{ml}$ per $\mathrm{kg}$ ) was withdrawn than dextran initially infused when the animals were returned to normovolemic volumes. As shown in Table II, this procedure led to nearly the same blood volumes in the first and third normovolemic periods.

\section{DISCUSSION}

Previous studies have led to conflicting opinions about the circulatory responses associated with an increase in blood volume. Most of the controversy concerns the effects of infusions of either whole blood or concentrated erythrocytes, whereas the effects of hemodilution hypervolemia on cardiac output are fairly constant. Virtually all of the experiments in both humans and dogs, with vascular volume expanders such as dextran, saline, and acacia, have demonstrated an elevated cardiac minute volume $(1,2,9-11)$. This increase could result from the change in either hematocrit or blood volume because cardiac output has been shown to rise consistently in anemia without a change in blood volume $(3,4)$, and at times following an increase in blood volume without a change in hematocrit $(12,13)$.

Fowler, Franch, and Bloom (1) investigated this problem and found that although a greater increase in mean cardiac output occurred in hypervolemic than normovolemic anemia, the difference was not statistically significant. A subsequent study (2) revealed an insignificant variation between cardiac output values at normal hematocrits in normovolemic and hypervolemic conditions. It was concluded from these studies that hematocrit and not blood volume determined the cardiac output response. Our data also indicate that anemia is associated with a rise in 
cardiac output, but contradict the previous interpretation by showing that there is a significant difference in the cardiac output values obtained when the hematocrit is varied under normovolemic and hypervolemic conditions.

Our experimental procedures differed from those of Fowler and co-workers in two important aspects: the amount of blood volume expansion and the presence or absence of the spleen. We used 50 to $70 \mathrm{ml}$ per $\mathrm{kg}$ in our experiments, and Fowler and co-workers used $80 \mathrm{ml}$ per $\mathrm{kg}(1,2)$. It is unlikely that the difference in volume accounts for the results, since a larger amount was given by Fowler's group $(1,2)$. Another explanation for the different results is that we were using previously splenectomized animals, and Fowler and co-workers $(1,2)$ were not. Although it has been shown that there is no difference in the cardiac output found in splenectomized and nonsplenectomized dogs (14), the ability of the spleen to act as a blood reservoir and mask vascular volume changes appears to vary under certain conditions. Gregg and Wiggers (5) observed that the spleen was "enormously distended" following the transfusion of concentrated erythrocytes; Gowdey, Hatcher, and Sunahara (10) found a "contracted" spleen after an infusion of large amounts of gum acacia; and Deavers, Huggins, and Smith (15) were unable to measure any change in splenic volume after transfusion of large volumes of whole blood. Splenectomized dogs were used in our experiments to avoid the variable sequestrating abilities of the spleen that seem to depend on the hematocrit of the infused substance.

Data from the present experiments are in agreement with previous work which demonstrates that cardiac output decreases in acutely induced normovolemic polycythemia $(3,4)$ and may increase in acute hypervolemic polycythemia (5). Whether or not the cardiac output is increased in hypervolemic polycythemia depends upon the hematocrit under consideration; for example, inspection of Figure 1 shows that cardiac output at a hypervolemic hematocrit of $60 \%$ is higher, while cardiac output at a hypervolemic hematocrit of $70 \%$ is lower than the cardiac output at a normovolemic hematocrit of $45 \%$. Furthermore, it is likely that the amount of volume expansion will vary the position of the hypervolemic values either closer to or further from the normovolemic data at comparable hematocrits. This analysis explains the observations of Cobb, Kramer, and Finch (16) that patients with primary polycythemia vera (mean hematocrit $60 \%$ ) associated with hypervolemia (58\% increase in blood volume) had high cardiac outputs. Holt (12) and Ferguson, Shadle, and Gregg (13) also found that the transfusion of whole blood led to an increased cardiac output. In the latter study, however, the results were not uniform. There are, in addition, other reports on the effects of whole blood transfusions that fail to show that hypervolemia causes any changes in the circulation. In 1909, Hess (17) maintained hypervolemia in rabbits by successive injections of whole blood. $\mathrm{He}$ concluded that there had been no chronic elevation in cardiac minute volume from a lack of myocardial hypertrophy at autopsy. Meck and Eyster (18) also inferred that hypervolemia did not change cardiac output because there was no measurable increase in heart size and because the plethora induced by blood transfusions was accommodated by the opening of capillaries and veins. More recently, Frye and Braunwald (19) studied the cardiovascular responses to whole blood transfusion in normal human subjects. They ascertained that there was only a small increase in cardiac output after the infusion of blood until the activity of the autonomic nervous system had been altered by the use of ganglionic blocking drugs. This observation may pertain to our own experiments in which pentobarbital anesthesia was used, since the level of anesthesia may have been sufficient to affect autonomic nervous activity and interfere with compensatory mechanisms that would normally prevent the responses we observed.

The mechanisms that determine the change in cardiac output when hematocrit is varied at any blood volume are not definitely established. The marked increase in viscosity at high hematocrits will cause a sufficient change in PVR to account for the observed decrease in cardiac output (20). The quantitative changes in viscosity which are found in anemia (20), however, are inadequate by a considerable margin to cause the measured reduction in PVR. This decrease can be explained if either the fall in viscosity makes a greater contribution to vascular resistance than previously 
held, or other factors lower vascular resistance that are not presently known.

Guyton, Lindsey, Kaufmann, and Abernathy (21) demonstrated that an increase in venous return, and hence cardiac output, will result from an elevation in the circulating blood volume. Part of the increase in flow was related to a reduction in resistance within veins caused by venous distention. Some distention may also occur in the systemic arterial vessels in hypervolemia, and the reduction in systemic arterial resistance would also contribute to an increase in blood flow. The higher cardiac output values in hypervolemic experiments are probably caused by the lower resistance to flow, at any comparable hematocrit, which results from the changed geometry of the blood vessels. The latter includes not only vessel distention but the opening of a-v communications as well.

Although $\mathrm{SaO}_{2}$ in normovolemia was significantly correlated to hematocrit in a previous study (4), no such relationship was found in the present normovolemic data. The variations in $\mathrm{SaO}_{2}$ may be accounted for by both analytical errors and ventilation perfusion abnormalities caused by the anesthesia. Neither mechanism, however, will account for the fall in $\mathrm{SaO}_{2}$ found in hypervolemic polycythemia in the present study. The difference in $\mathrm{SaO}_{2}$ values between normovolemia and hypervolemia at high hematocrits is nearly significant $(p=0.07)$. Oxygen saturation was even lower in hypervolemia at hematocrits $>65 \%$. In polycythemia vera, an analogous disorder, a similar reduced oxygen saturation was found that was thought to result from an increase in venous admixture (22). The reduced arterial saturation in our studies probably results from a similar shunting phenomenon that could have an anatomical origin (pulmonary a-v communications), or result from ventilation-perfusion abnormalities. The latter could arise from either local disturbances in ventilation, or failure to oxygenate completely the increased red-cell mass as it flows through engorged pulmonary capillaries.

The inverted U-shaped curve for $\mathrm{SO}_{2} \mathrm{~T}$ with its peak in the normal hematocrit range is similar to that described in our previous investigation on normovolemic hematocrit changes (4). The higher curve in hypervolemia is caused primarily by the greater cardiac output associated with an increase in blood volume. Of interest is the observation in hypovolemia experiments of a parallel curve at a lower level that also reaches its peak in the normal hematocrit range (23).

The parabolic configuration of all of these curves is determined by the fact that cardiac output is linearly related to hematocrit in the range studied. The hematocrit limits arterial oxygen capacity by the amount of hemoglobin within the cells. The equations for the regression lines derived from the cardiac output-hematocrit data shown in Figure 1 are $\dot{Q}=285-3.70$ hematocrit (normovolemia) and $\dot{Q}=453-4.88$ hematocrit (hypervolemia); these lines intersect the abscissa (i.e., cardiac output would be zero) at hematocrits of $77.2 \%$ and $92.8 \%$, respectively. $\mathrm{SO}_{2} \mathrm{~T}$ is necessarily zero at points of zero cardiac output and hematocrit; maximal oxygen delivery occurs halfway between these points at hematocrits of $38.6 \%$ (normovolemia) and $46.4 \%$ (hypervolemia). The exact position of the curve will be affected slightly by $\mathrm{SaO}_{2}$, which varies as hematocrit is changed, especially in hypervolemia.

Because $\mathrm{SO}_{2} \mathrm{~T}$ represents the maximal oxygen available to the body per minute, it is the limiting factor to the metabolic expenditure of the organism. The fact that peak $\mathrm{SO}_{2} \mathrm{~T}$ occurs within the normal hematocrit range irrespective of the blood volume may have clinical implications in the many hypervolemic disorders known to exist.

\section{SUMMARY}

1. Studies were made of the effects of acute hematocrit variations in 20 dogs with either normal or increased blood volumes. Measurements included cardiac output, peripheral vascular resistance (PVR), arterial oxygen saturation $\left(\mathrm{SaO}_{2}\right)$, and systemic oxygen transport $\left(\mathrm{SO}_{2} \mathrm{~T}\right)$.

2. Cardiac output had a significant inverse correlation to hematocrit in both normovolemic and hypervolemic experiments. There was, in addition, a significant difference in the magnitude of the cardiac output response obtained when blood volume was either normal or increased; cardiac output was approximately twice as high in hypervolemic as in normovolemic experiments at any comparable hematocrit. In both volume groups, the change in cardiac output was related more to variations in stroke volume than heart rate. 
3. In both blood-volume groups studied, there was a rise in PVR that became progressively greater as hematocrit increased. In hypervolemic studies, the PVR was approximately half that which occurred in normovolemic experiments at any comparable hematocrit.

4. $\mathrm{SaO}_{2}$ values in normovolemia tended to rise as hematocrit increased, but this correlation was not statistically significant. The opposite relationship occurred in hypervolemic studies; $\mathrm{SaO}_{2}$ decreased significantly as hematocrit increased.

5. A plot of $\mathrm{SO}_{2} \mathrm{~T}$ against hematocrit for normovolemic and hypervolemic experiments resulted in inverted U-shaped curves with peaks in the normal hematocrit range. $\mathrm{SO}_{2} \mathrm{~T}$ was approximately twice as high in hypervolemic as in normovolemic studies at any comparable hematocrit.

6. We concluded from these studies that both the blood volume and hematocrit level have independent regulatory effects on the circulation; the observed changes depended upon the interaction of these two variable parameters.

\section{ACKNOWLEDGMENTS}

The authors acknowledge gratefully the technical assistance of Liana Nebel and Ardis Clark. Dr. Victor E. Hall kindly reviewed the manuscript.

\section{REFERENCES}

1. Fowler, N. O., R. H. Franch, and W. L. Bloom. Hemodynamic effects of anemia with and without plasma volume expansion. Circulat. Res. 1956, 4, 319.

2. Fowler, N. O., W. L. Bloom, and J. A. Ward. Hemodynamic effects of hypervolemia with and without anemia. Circulat. Res. 1958, 6, 163.

3. Richardson, T. Q., and A. C. Guyton. Effects of polycythemia and anemia on cardiac output and other circulatory factors. Amer. J. Physiol. 1959, $197,1167$.

4. Murray, J. F., P. Gold, and B. L. Johnson, Jr. Systemic oxygen transport in induced normovolemic anemia and polycythemia. Amer. J. Physiol. 1962, 203, 720.

5. Gregg, D. E., and C. J. Wiggers. The circulatory effects of acute experimental hypervolemia. Amer. J. Physiol. 1933, 104, 423.

6. Van Slyke, D. D., and J. M. Neill. The determination of gases in blood and other solutions by vacuum extraction and manometric measurements. Int. J. biol. Chem. 1924, 61, 523.

7. Snedecor, G. W. Statistical Methods, 5th ed. Ames, Iowa, Iowa State College Press, 1956.

8. Gullbring, B., A. Holmgren, T. Sjöstrand, and T. Strandell. The effect of blood volume variations on the pulse rate in supine and upright positions and during exercise. Acta physiol. scand. 1960, 50, 62.

9. McMichael, J., and E. P. Sharpey-Schafer. Cardiac output in man by a direct Fick method. Effects of posture, venous pressure change, atropine and adrenaline. Brit. Heart J. 1944, 6, 33.

10. Gowdey, C. W., J. D. Hatcher, and F. A. Sunahara. Cardiovascular responses in dogs to large intravenous infusions. Canad. J. Biochem. 1954, 32, 282.

11. Schnabel, T. G., Jr., H. Eliasch, B. Thomasson, and L. Werkö. The effect of experimentally induced hypervolemia on cardiac function in normal subjects and patients with mitral stenosis. J. clin. Invest. 1959, 38, 117.

12. Holt, J. P. Effect of plethora and hemorrhage on left ventricular volume and pressure. Circulat. Res. 1957, 5, 273.

13. Ferguson, T. B., O. W. Shadle, and D. E. Gregg. Effect of blood and saline infusion on ventricular end diastolic pressure, stroke work, stroke volume and cardiac output in the open and closed chest dog. Circulat. Res. 1953, 1, 62.

14. Smith, L. L., R. L. Foster, and W. Muller. Intrinsic cardiac output variability in the anesthetized normal and splenectomized dog. Amer. J. Physiol. 1962, 202, 1155.

15. Deavers, S., R. A. Huggins, and E. L. Smith. Changes in cell and plasma volumes of various organs produced by a massive transfusion in dogs. Amer. J. Physiol. 1957, 191, 159.

16. Cobb, L. A., R. J. Kramer, and C. A. Finch. Circulatory effects of chronic hypervolemia in polycythemia vera. J. clin. Invest. 1960, 39, 1722.

17. Hess, R. Künstliche Plethora und Herzarbeit. Dtsch Arch. klin. Med. 1909, 95, 482.

18. Meck, W. J., and J. A. E. Eyster. The effect of plethora and variations in venous pressure on diastolic size and output of the heart. Amer. J. Physiol. 1922, 61, 186.

19. Frey, R. L., and E. Braunwald. Studies on Starling's Law of the heart. I. The circulatory response to acute hypervolemia and its modification by ganglionic blockade. J. clin. Invest. 1960, 39, 1043.

20. Levy, M. N., and L. Share. The influence of erythrocyte concentration upon the pressure-flow relationships in the dog's hind limb. Circulat. Res. 1953, 1, 247.

21. Guyton, A. C., A. W. Lindsey, B. N. Kaufmann, and J. B. Abernathy. Effect of blood transfusion and hemorrhage on cardiac output and on the venous return curve. Amer. J. Physiol. 1958, 194, 263.

22. Lillehei, J. P., R. L. Johnson, Jr., N. Wu, E. R. Halden, and B. J. Sproule. Venous-arterial admixture in the lungs in primary and secondary polycythemia. Circulation 1958, 17, 1029.

23. Crowell, J. W., R. G. Ford, and V. M. Lewis. Oxygen transport in hemorrhagic shock as a function of the hematocrit ratio. Amer. J. Physiol. 1959, 196, 1033 , 